\title{
Diversity of cultured bacteria from the perennial ice block of Scărişoara Ice Cave, Romania
}

\author{
Corina Ițcuş ${ }^{1}$, Mădălina-Denisa Pascu ${ }^{1}$, Traian $B{ }^{1,2}{ }^{1,2}$, Aurel Perşoiu ${ }^{1,2,3}$, and Cristina Purcarea ${ }^{1^{*}}$ \\ ${ }^{1}$ Institute of Biology Bucharest of the Romanian Academy, 296 Spl. Independentei, Bucharest 060031, Romania \\ ${ }^{2}$ Emil Racoviță Institute of Speleology, 5 Clinicilor St., Cluj-Napoca 400006, Romania \\ ${ }^{3}$ Stable Isotope Laboratory, Stefan cel Mare University, 13 Universitatii St., Suceava 720229, Romania
}

\begin{abstract}
Cave ice ecosystems represent a poorly investigated glacial environment. Diversity of cave ice bacteria and their distribution in perennial ice deposits of this underground glacial habitat could constitute a proxy for microbial response to climatic and environmental changes. Scărişoara Ice Cave (Romania) hosts one of the oldest and largest cave ice blocks worldwide. Here we report on cultured microbial diversity of recent, 400, and 900 years-old perennial ice from this cave, representing the first characterization of a chronological distribution of cave-ice bacteria. Total cell density measured by SYBR Green I epifluorescence microscopy varied in the $2.4 \times 10^{4}-2.9 \times 10^{5}$ cells $\mathrm{mL}^{-1}$ range. The abundance of cultured bacteria $\left(5 \times 10^{2}-8 \times 10^{4} \mathrm{CFU} \mathrm{\textrm {mL } ^ { - 1 }}\right.$ ) representing $0.3-52 \%$ of the total cell number decreased exponentially with the ice age, and was higher in organic rich ice sediments. Cultivation at $4^{\circ} \mathrm{C}$ and $15^{\circ} \mathrm{C}$ using BIOLOG EcoPlates revealed a higher functional diversity of cold-active bacteria, dependent on the age, sediment content and physicochemical properties of the ice. The composition dissimilarity of ice microbiota across the ice block was confirmed by growth parameter variations when cultivated in different liquid media at low and high temperatures. PCR-DGGE and sequencing of bacterial 16S rRNA gene fragments from the cultured ice samples led to the identification of 77 bacterial amplicons belonging to Gammaproteobacteria, Firmicutes, Bacteroidetes, and Actinobacteria, showing variation in distribution across the ice layers. Several identified OTUs were homologous to those identified in other glacial and karst environments and showed partial conservation across the ice block. Moreover, our survey provided a glimpse on the cave-ice hosted bacteria as putative biomarkers for past climate and environmental changes.
\end{abstract}

Keywords: $\quad$ ice cave; bacteria; biodiversity; 16S rRNA gene; Scărişoara

Received 17 August 2015; Revised 25 January 2016; Accepted 25 January 2016

Citation: Iţcuş C., Pascu M.-D., Brad T., Perşoiu A. and Purcarea C., 2016. Diversity of cultured bacteria from the perennial ice block of Scărişoara Ice Cave, Romania. International Journal of Speleology, 45 (1), 89-100. Tampa, FL (USA) ISSN 0392-6672

http://dx.doi.org/10.5038/1827-806X.45.1.1948

\section{INTRODUCTION}

The increased interest in microbial communities from various frozen environments has focused on understanding their mechanism of adaptation and role in these habitats. In spite of the in depth investigation of the structural and functional microbial diversity in frozen environments (Price, 2007; Priscu et al., 2007; Margesin \& Miteva, 2011; Gunde-Cimerman et al., 2012) such as polar ice sheets and glaciers (Miteva et al., 2004, Lanoil et al., 2009; Rehakova et al., 2010; Anesio \& Laybourn-Parry, 2012), permafrost (Rivkina et al., 2004), mountain glacier forefields (Lapanje et al., 2012; Zumsteg et al., 2012), frozen lakes (Felip et al., 1995), sea ice (Deming, 2002), Arctic (Varin et al., 2010; Adams et al., 2014) and Antarctic permanent lake ice (Priscu et al., 1998; Dieser et al., 2010, Murray et al., 2012), very little is known about microbial communities present in cave-hosted perennial ice accumulations. Such habitats are found in caves from mid-latitude, mid-altitude mountains, where the combination of cave morphology and local climatic conditions allow for the year-round preservation of ice and associated azonal glacial climatic conditions (Perşoiu \& Onac, 2012). These limited reports include isolation of bacterial species (Margesin et al., 2004) and diatom flora (Lauriol et al., 2006) from this type of habitat. Recent investigations of the microbial communities from volcanic ice caves formed on Mount Erebus, Antarctica, revealed a low diversity of bacteria and fungi in this extreme subsurface habitat (Tebo et al., 2015). However, no data on the chronological 
distribution of bacteria in ice caves have been reported so far.

Scărişoara Ice Cave, located in the Bihor Mountains, NW Romania, $\left(46^{\circ} 29^{\prime} 23^{\prime \prime} \mathrm{N}\right.$ $22^{\circ} 48^{\prime} 35^{\prime \prime} \mathrm{E}, 1165 \mathrm{~m}$ asl) is a limestone cave hosting one of the oldest ( $>3,500$ years) and largest $\left(>100,000 \mathrm{~m}^{3}\right)$ perennial underground ice blocks in the world (Holmlund et al., 2005; Perşoiu \& Pazdur, 2011). Over the last century its underground ice block was extensively studied in order to understand climatic and glaciological processes (Racoviță, 1927; Şerban et al., 1947; Racoviță, 1994, Racoviță \& Onac, 2000). More recently, it became the subject of studies aiming to reconstruct climatic and environmental changes in the region (Onac et al., 2007; Feurdean et al., 2011; Perşoiu et al., 2011a; Perşoiu \& Pazdur, 2011). Unlike surface glaciers and glacier caves, the perennial ice from this cave was formed by water freezing (Perşoiu et al., 2011a). Between spring and late autumn, water infiltrates in the Great Hall area (Fig. 1A,B), forming a shallow lake (up to $20 \mathrm{~cm}$ deep) on top of the existing ice block. During winter, the entire lake freezes resulting in a $\sim 20-\mathrm{cm}$ thick ice layer that traps at the bottom various sediments deposited during summer. Therefore, the resulted ice block consists of ice layers of variable thickness separated by organicand inorganic-rich sediment layers (Perşoiu et al., 2011a; Perşoiu \& Pazdur, 2011). Nitrifying bacteria were identified in the limestone area of Scărişoara Ice Cave more than six decades ago (Pop, 1949). Our recent investigation of the ice deposits from this cave reported the presence of cultured bacteria in one-year old ice stalagmites formed in the Little Reservation area (Fig. 1A, C), belonging to Pseudomonas, Bacillus and Paenibacillus genera (Hillebrand-Voiculescu et al., 2013). In addition, preliminary data indicated the presence of bacterial and eukaryotic SSU rRNA genes in samples collected from 1, 400 and 900 years old ice-block layers, and the occurrence of phototrophic microorganisms in sun- and light-exposed ice using epifluorescence microscopy (Hillebrand-Voiculescu et al., 2014).

Here, we investigated the structural and functional diversity of cultured bacteria throughout the perennial ice block of Scărişoara Cave in correlation with its physicochemical and chemical parameters, using BIOLOG EcoPlates, PCR-DGGE and phylogenetic analysis of bacterial 16S rRNA gene sequences from the culturable microbial fraction isolated from five different locations of the subterranean ice. Our findings highlighted the heterogeneous distribution of cave ice-bacteria in sequential ice layers up to $900 \mathrm{yr}-$ old characterized by various light exposure regimes (dark, indirect and direct sunlight) and organic matter content (clear ice and sediment-rich ice). This data, contributing to the microbial characterization of Scărişoara Ice Cave ecosystem, represents the first report on bacterial chronosequence in ice deposits from a limestone cave.

\section{MATERIALS AND METHODS}

\section{Ice sampling}

Ice samples of different ages were collected from ${ }^{14} \mathrm{C}$-dated ice layers of the perennial ice block from Scărişoara Ice Cave (Perşoiu \& Pazdur, 2011). Five different samples of 1 (AD 2012), 400 (385 cal BP) and 900 (943 cal BP) years old ice were extracted from the ice block. Recent (1 year old) ice samples originated from the Great Hall from a sun-exposed site (sample 1-S) in the immediate vicinity of the entrance, and from an indirect light exposed area (sample 1-L), in the center of the cave (Fig. 1B). These samples were collected from the top of the ice block by vertical drilling, after removing $\sim 5 \mathrm{~cm}$ of the superficial layer. The 400 (400-0), and 900 (900-0 and 900-I) yr-old ice samples were collected from the Little Reservation ice wall (Fig. 1C) by horizontal drilling, after removing $\sim 20 \mathrm{~cm}$ of the ice wall surface. Both 400-O and 900-O samples correspond to organic-rich ice layers, while 900-I represent clear ice (Fig. 1D). Sampling was carried out in triplicate from each location, under aseptic conditions (Hillebrand-Voiculescu et al., 2014). The ice surface was flamed for 5-10 s prior to 
the drilling procedure, and both the outer and inner surfaces of the coring auger $(5-\mathrm{cm}$ diameter, $50-\mathrm{cm}$ length) were decontaminated with 96\% ethanol and flaming after each drilling step. Ice samples were collected in sterile 1-L flasks, in the presence of an open-flame laboratory torch.

\section{Physicochemical and chemical analyses}

Carbon and nitrogen contents of the ice samples $(0.5 \mathrm{~mL})$ melted at $4{ }^{\circ} \mathrm{C}$ were determined using a Multi N/C 3100 elemental combustion analyzer (Analytik Jena, Jena, Germany). Total nitrogen content (TN) was measured using a furnace temperature of $850^{\circ} \mathrm{C}$, and the carbon content, comprising total carbon (TC) and inorganic carbon (IC), was determined at $800^{\circ} \mathrm{C}$. Total organic carbon content (TOC) was calculated by subtracting inorganic carbon IC from the total carbon TC values. The average values of the carbon and nitrogen contents, expressed as $\mathrm{mg} \mathrm{mL}^{-1}$ melted ice, and the standard deviations were calculated from three replicates. The $\mathrm{pH}$, electrical conductivity (EC), and total dissolved solids (TDS) values of the melted ice samples were measured at $22^{\circ} \mathrm{C}$ using a Multiparameter HI9828 water quality meter (Hanna Instruments, Woonsocket, RI, USA).

\section{Cultivation and cell density of ice-contained bacteria}

Ice-contained heterotrophic bacteria were cultivated on various growth media: T1 $\left(5 \mathrm{~g} \mathrm{~L}^{-1}\right.$ peptone, $0.15 \mathrm{~g}$ $\mathrm{L}^{-1}$ ferric ammonium citrate, $0.2 \mathrm{~g} \mathrm{~L}^{-1} \mathrm{MgSO}_{4} \cdot 7 \mathrm{H}_{2} \mathrm{O}$, $0.05 \mathrm{~g} \mathrm{~L}^{-1} \mathrm{CaCl}_{2}, 0.05 \mathrm{~g} \mathrm{~L}^{-1} \mathrm{MnSO}_{4} \cdot 4 \mathrm{H}_{2} \mathrm{O}, 0.01 \mathrm{~g} \mathrm{~L}^{-1}$ $\mathrm{FeCl}_{3} \cdot 6 \mathrm{H}_{2} \mathrm{O}$ (Bidle et al., 2007)), T2 ( $1 \mathrm{~g} \mathrm{~L}^{-1}$ glucose, $1 \mathrm{~g} \mathrm{~L}^{-1}$ peptone, $0.5 \mathrm{~g} \mathrm{~L}^{-1}$ yeast extract, $0.2 \mathrm{~g} \mathrm{~L}^{-1} \mathrm{MgSO}_{4} \cdot 7 \mathrm{H}_{2} \mathrm{O}$, $0.05 \mathrm{~g} \mathrm{~L}^{-1} \mathrm{MnSO}_{4} \cdot 4 \mathrm{H}_{2} \mathrm{O}$ (Bidle et al., 2007)), Luria broth (LB), and LB containing $10 \mathrm{~g} \mathrm{~L}^{-1}$ glucose (LBG). Ice samples $(0.5 \mathrm{ml})$ were thawed at $4^{\circ} \mathrm{C}$ and used for liquid media inoculation $(1: 10 \mathrm{v}: \mathrm{v})$. Bacterial cultures were incubated at $4^{\circ} \mathrm{C}$ and $15^{\circ} \mathrm{C}$ with shaking for 20 and 17 days, respectively. Cell growth was monitored by measuring the $\mathrm{OD}_{600}$ using a FluoStar Omega plate reader (BGM Labtech, Ortenberg, Germany). The growth parameters, doubling time (DT), and lag time were calculated using the DoublingTime exponential least square fitting software (Roth, 2006), and the linear fit of the exponential phase slope, respectively. The average values and standard deviations were calculated from two experimental data sets.

The total cell density of ice bacteria was determined by enumeration of SYBR Green I labeled cells using epifluorescence microscopy (Noble \& Fuhrman, 1998). Melted ice samples (2 $\mathrm{ml})$ were sonicated for 30 minutes in the presence of 10\% Tween 20 (Fluka Chemie GmbH, Buchs, Switzerland), and further incubated for 15 minutes with SYBR Green I Dye (Thermo Fisher Scientific, Waltham, MA, USA). After passing on $0.22 \mathrm{~mm}$ pore size filters (Merck Millipore, Billerica, MA, USA), the strain cells were counted using an AXIO Scope A1 epifluorescence microcope (Carl Zeiss, Oberkochen, Germany).

The cell content of cultured heterotrophs from ice samples was determined by cultivation on R2A medium, commonly used for cultivation of heterotrophs from cold habitats (Reasoner \& Geldreich, 1985; Miteva et al, 2004; Yu \& Margesin, 2014), at both $4^{\circ} \mathrm{C}$ and $15^{\circ} \mathrm{C}$. The plates were inoculated with $100 \mathrm{ml}$ of melted ice diluted $1: 1,1: 10,1: 100$ and $1: 1000$ in sterile water, and incubated at $4^{\circ} \mathrm{C}$ and $15^{\circ} \mathrm{C}$ for 51 and 13 days, respectively. The average cell density and standard deviation values were calculated from triplicate data sets, and expressed as number of colony forming units (CFU) $\mathrm{mL}^{-1}$ of melted ice.

\section{BIOLOG EcoPlates}

The functional diversity of culturable bacteria from recent and old ice layers was investigated using Biolog EcoPlates (Garland \& Mills, 1991; Lehman et al., 1995). The 96-well microplates containing 31 different carbon sources in triplicate were inoculated with 300 $\mathrm{ml}$ of melted ice, and incubated at $4^{\circ} \mathrm{C}$ for 68 days and at $15^{\circ} \mathrm{C}$ for 46 days. The color development was monitored daily using a FluoStar Omega plate reader (BGM Labtech, Ortenberg, Germany).

The carbon-source utilization pattern was analyzed based on the calculated parameters average well-color development (AWCD), substrate richness (R), ShannonWeaver diversity index $(\mathrm{H})$, and Shannon substrate evenness (E), computed for each well (i) asAWCD $=\Sigma O D_{i} / 31$ (Garland \& Mills, 1991), $\mathrm{R}=$ number of metabolized substrates (positive OD readings), $\mathrm{H}=$ $-\Sigma \mathrm{pi}\left(\ln \mathrm{p}_{\mathrm{i}}\right)$, where $\mathrm{p}_{\mathrm{i}}=\mathrm{OD}_{\mathrm{i}} / \Sigma O \mathrm{D}_{\mathrm{i}}$, and $\mathrm{E}=\mathrm{H} / \operatorname{lnR}($ Garland, 1997; Insam \& Goberna, 2004). These parameters were calculated using the average absorbance values of the triplicate reads, after subtracting the blank (absorbance on the well containing no C-substrate), and using a $0.25\left(\mathrm{OD}_{590}\right)$ threshold value for positive growth response. The computed parameters corresponded to 42 -days growth at $4^{\circ} \mathrm{C}$, and 30 -days growth at $15^{\circ} \mathrm{C}$, representing the shortest incubation time for reaching maximum AWCD (plateau phase) for all the samples (Pessi et al., 2012).

\section{DNA extraction and PCR amplification}

Genomic DNA was extracted from the melted ice samples cultivated on T1, T2, LB and LBG media using DNeasy Blood and Tissue kit (Qiagen, Valencia, CA, USA) by a modified protocol including two initial cell lysis steps. The cell pellet from 4-mL culture was incubated for 1 hour at $37^{\circ} \mathrm{C}$ in the presence of 200 $\mathrm{ml}$ TE containing 20 units mutanolysin (Fermentas, Waltham, MA, USA) per gram of cell pellet, to disrupt the Gram-positive bacterial cell wall. The resulted extract was incubated for $30 \mathrm{~min}$ at $56^{\circ} \mathrm{C}$ with 12 units proteinase $\mathrm{K}$ per gram of cell pellet, in the presence of ZR bashing beads (Zymo Research Corporation, Irvine, CA, USA), using a Homogenization system SpeedMill PLUS (Analytic Jena), and further processed according to the manufacturer protocol.

PCR amplification of bacterial 16S rRNA gene fragments for DGGE analysis was performed using a Thermal Cycler C1000 ${ }^{\mathrm{TM}}$ (Bio-Rad Laboratories, Hercules, CA, USA). The reaction consisted of an initial 2-min denaturation step at $95^{\circ} \mathrm{C}, 35$ cycles of $30 \mathrm{~s}$ at $95^{\circ} \mathrm{C}, 1 \mathrm{~min}$ at $54^{\circ} \mathrm{C}$, and $1 \mathrm{~min}$ at $72^{\circ} \mathrm{C}$, and a final 5-min elongation step at $72^{\circ} \mathrm{C}$ (Muyzer et al., 1993). The amplification mixture contained 40-100 ng DNA template, $0.2 \mu \mathrm{M}$ of forward (F357- 
GC: 5'- CGC CCG CCG CGC GGC GGG CGG GGC GGG GGC ACG GGG CCT ACG GGA GGC AGC AG3') and reverse (R518: 5'-ATT ACC GCG GCT GCT GG-3') primers, 1xDreamTaq buffer containing $2 \mathrm{mM}$ $\mathrm{MgCl}_{2}, 0.2 \mathrm{mM}$ dNTP mix (Thermo Fisher Scientific), and 5 U DreamTaq DNA polymerase (Thermo Fisher Scientific), in a final volume of $50 \mathrm{ml}$. The presence and size of the PCR products were visualized by $1 \%$ agarose (w/v) gel electrophoresis.

\section{DGGE}

To assess the diversity of cultured ice-contained bacteria, DGGE analysis of the 16S rRNA gene fragments was performed using a DGGE-4801-220 system (CBS Scientific). Amplicons (0.5-1 mg) were loaded onto $8 \%$ denaturing polyacrylamide gels containing 37.5:1 acrylamide/ bisacrylamide (Carl Roth, Karlsruhe, Germany) and a 30-55\% ureaformamide linear gradient, where $100 \%$ corresponded to $7 \mathrm{M}$ urea (Serva, Heidelberg, Germany) and 40\% formamide (Carl Roth, Karlsruhe, Germany) Samples were migrated for $4 \mathrm{~h}$ in TAE buffer (Lonza Group, Basel, Switzerland) at $60^{\circ} \mathrm{C}$ and $220 \mathrm{~V}$. After staining for $90 \mathrm{~min}$ at $20^{\circ} \mathrm{C}$ with $0.1 \mu \mathrm{g} \mathrm{mL} \mathrm{m}^{-1}$ ethidium bromide (Sigma-Aldrich, St. Louis, MO, USA), the DNA fragments were excised from the gel, incubated in $20 \mathrm{ml}$ sterile MilliQ water at $4^{\circ} \mathrm{C}$ for $48 \mathrm{~h}$, and reamplified by PCR as described above. Amplicon sequencing was carried out using the R518 bacterial primer (Macrogen, Amsterdam, The Netherland).

The sequences reported in this study (bacterial 16S rRNA DGGE fragments) were assigned the GenBank accession numbers KF85203-KF853221, KJ454416KJ454425, and KP219085-KP2 19133.

\section{Sequence analysis}

The DNA sequences were edited using CodonCode Aligner (www.codoncode.com) and BioEdit (Hall, 2007) for eliminating the false gaps and sequencing errors.
The closest match of each OTU was determined using the BLAST-NCBI Megablast algorithm and the nucleotide collection database (Altschul et al., 1997).

\section{Statistical analysis}

The response of ice-embedded microbial communities to the used carbon source based on microbial growth $\left(\mathrm{OD}_{590}\right)$ on 31 different substrates at 4 and $15^{\circ} \mathrm{C}$ using BIOLOG EcoPlates, and their functional diversity $(\mathrm{H})$ dependence on ice (physico) chemical parameters were analyzed by Principal Component Analysis (PCA) using the Excel add-in Multibase 2015 Solver (Numerical Dynamics, Japan). The ordination plots were constructed using Past 3.0 software (Kemple et al., 1989).

\section{RESULTS}

\section{Ice physicochemical and chemical properties}

In order to correlate the cell density and diversity of cultured bacteria with the physicochemical characteristics of the ice substrate, the carbon and nitrogen content, along with the $\mathrm{pH}, \mathrm{EC}$, and TDS parameters of recent and old ice samples were determined. The results (Table 1) indicated mildly alkaline $\mathrm{pH}$ values (7.5-7.6) for the recent (1-S, 1-L) and 400-O ice samples, with a slight increase for the older 900-O (pH 7.9) and 900-I ( $\mathrm{pH}$ 8.0) samples. The electrical conductivity of melted ice samples varied with both the age and organic content of the sediment. Thus, the highest $\mathrm{EC}$ value (124 $\mathrm{mS} \mathrm{cm}^{-1}$ ) was measured for $1-\mathrm{S}$, showing a 2 -fold decrease for both 1 -L and 400-O samples. The lowest conductivity $\left(15-17 \mathrm{mS} \mathrm{cm}^{-1}\right)$ was recorded for the oldest ice samples 900-O and 900-I. In accordance, TDS concentrations decreased with the ice age, ranging from $7 \mathrm{mg} \mathrm{L}^{-1}$ to $62 \mathrm{mg} \mathrm{L}^{-1}$, with the exception of 1 -L and 400-O that showed similar TDS values (Table 1$)$.

Table 1. Physicochemical and chemical properties of ice samples. The $\mathrm{pH}$, electrical conductivity (EC), and total disolved solids (TDS) values of melted ice samples 1-S, 1-L, 400-O, 900-O and 900-I were measured at $22^{\circ} \mathrm{C}$. Samples differ by their age (1, 400 and 900 years old), light regime (sun (S) and indirect light (L) exposure), and sediment content (organic sediment $(\mathrm{O})$ and clear ice (I) content). The average values and standard deviation of total carbon (TC), inorganic carbon (IC), total organic carbon (TOC) and total nitrogen (TN) contents of ice samples were calculated from three different measurements. TC/TN represents the ratio of TC and TN values.

\begin{tabular}{|c|c|c|c|c|c|c|c|c|}
\hline Sample & $\mathbf{p H}$ & $\begin{array}{c}\mathbf{E C} \\
\left(\mu \mathrm{Cm}^{-1}\right)\end{array}$ & $\begin{array}{c}\text { TDS } \\
\left(\mathrm{mg} \mathrm{L}^{-1}\right)\end{array}$ & $\begin{array}{c}\text { TC } \\
\left(\mathrm{mg} \mathrm{L}^{-1}\right)\end{array}$ & $\begin{array}{c}\mathbf{I C} \\
\left(\mathrm{mg} \mathrm{L}^{-1}\right)\end{array}$ & $\begin{array}{c}\text { TOC } \\
\left(\mathrm{mg} \mathrm{L}^{-1}\right)\end{array}$ & $\begin{array}{c}\text { TN } \\
\left(\mathrm{mg} \mathrm{L}^{-1}\right)\end{array}$ & TC/TN \\
\hline 1-S & 7.48 & 124.2 & 61.9 & $41.97 \pm 0.47$ & $8.60 \pm 0.07$ & $33.38 \pm 0.48$ & $2.15 \pm 0.03$ & $19.52 \pm 0.47$ \\
\hline 1-L & 7.57 & 65.1 & 32.0 & $20.52 \pm 0.44$ & $9.25 \pm 0.04$ & $11.28 \pm 0.45$ & $0.53 \pm 0.01$ & $38.72 \pm 0.44$ \\
\hline $\mathbf{4 0 0 - 0}$ & 7.45 & 61.6 & 30.3 & $43.72 \pm 0.95$ & $13.76 \pm 0.07$ & $29.96 \pm 0.95$ & $2.23 \pm 0.03$ & $19.60 \pm 0.95$ \\
\hline 900-0 & 7.87 & 17.3 & 9.0 & $12.32 \pm 0.30$ & $5.84 \pm 0.04$ & $6.48 \pm 0.30$ & $0.62 \pm 0.01$ & $19.87 \pm 0.30$ \\
\hline 900-I & 8.03 & 15.0 & 7.0 & $8.46 \pm 0.12$ & $5.42 \pm 0.01$ & $3.03 \pm 0.12$ & $0.64 \pm 0.09$ & $13.22 \pm 0.15$ \\
\hline
\end{tabular}

Chemical analysis of melted ice samples showed variations of the total carbon (TC), organic carbon (TOC) and total nitrogen (TN) contents (Table 1). The highest TC, TOC and TN content $\left(\sim 40 \mathrm{mg} \mathrm{L}^{-1}\right)$ were measured for 1-S and 400-O ice samples, while 1-L and 900$\mathrm{O} / \mathrm{I}$ samples had 4-fold lower values. The two organicrich samples 1-S and 400-O also had the highest TOC content $\left(\sim 30 \mathrm{mg} \mathrm{L}^{-1}\right)$, representing $80 \%$ and $68 \%$ of the TC content, respectively. Moreover, a 3-fold lower TOC value was measured for the recent ice sample $1-\mathrm{L}$, while the oldest ice samples $900-\mathrm{O} / \mathrm{I}$ showed 5 to 8-fold lower values as compared to that of 1 -S. The ice inorganic carbon IC content was generally low (5-14 $\mathrm{mg} \mathrm{L}^{-1}$ ), representing $20-31 \%$ of the TC content in $1-\mathrm{S}$ and $400-\mathrm{O}$, and $45-64 \%$ in $1-\mathrm{L}$, and $900-\mathrm{O} / \mathrm{I}$ samples. The highest TN content was found in 1-S and 400-O, which decreased by about 4-fold in 1-L and 900$\mathrm{O} / \mathrm{I}$. The organic rich sediments $1-\mathrm{S}, 400-\mathrm{O}$ and 900$\mathrm{O}$ presented similar TC/TN values of approximately $20 \mathrm{mg} \mathrm{L}^{-1}$, while the clear recent ice sample 1-L had a 2-fold higher TC/TN ratio. The lowest TC/TN score (13 $\left.\mathrm{mg} \mathrm{L}^{-1}\right)$ was found for the 900-I ice deposit. 
Growth and enumeration of cultured

heterotrophic bacteria

Heterotrophic bacteria from Scărişoara ice samples were cultivated on both solid (R2A) and liquid (T1, $\mathrm{T} 2, \mathrm{LB}$, and $\mathrm{LBG}$ ) media at $4^{\circ}$ and $15^{\circ} \mathrm{C}$, in order to calculate the cell density and growing parameters of the culturable bacterial communities present in the ice block.

\section{Bacterial abundance}

The total cell density of ice bacteria stained with SYBR green 1 and measured by epifluorescence microscopy varied in the $2.4-22.3 \times 10^{4}$ cells $\mathrm{mL}^{-1}$ range (Table 2). The highest bacterial content was found in 1-S and 400-O ice samples, while both 900 yr-old ice samples (900-O/I) showed a 10-fold decrease in microbial cell density. 1-L recent ice exhibited 2-fold lower cell content relative to that of the same aged ice sample $1-\mathrm{S}$.

When grown on R2A medium at $4^{\circ} \mathrm{C}$ and $15^{\circ} \mathrm{C}$, the culturable cell number ranged from $0.7 \times 10^{2} \mathrm{CFU}$ $\mathrm{mL}^{-1}$ to $7.8 \times 10^{4} \mathrm{CFU} \mathrm{mL} \mathrm{mL}^{-1}$ (Table 2 ). At $4^{\circ} \mathrm{C}, 1-\mathrm{S}, 1-\mathrm{L}$ and 400-O samples contained $5-8 \times 10^{4} \mathrm{CFU} \mathrm{mL}^{-1}$, while in the oldest ice 900-O and 900-I the cell density was 50-100-fold lower. The bacterial communities from the recent ice samples $1-\mathrm{L}$ and $1-\mathrm{S}$ also exhibited the highest cell density (1-4.3 x $\left.10^{4} \mathrm{CFU} \mathrm{mL}^{-1}\right)$ when cultivated at $15^{\circ} \mathrm{C}$ (Table 2), whereas the old ice layers showed a 10-fold (400-O), 100-fold (900-O), and 600-fold (900-I) lower culturable population at this temperature. The density of bacteria cultivated at $4^{\circ} \mathrm{C}$ was higher than that growing at $15^{\circ} \mathrm{C}$ for all analyzed ice sediments (Table 2), suggesting a higher viability of cold-active microorganisms, particularly in the old ice layers. Moreover, on R2A, the cell density of bacteria from organic-rich ice layers 1-S, 400-O and 900-O cultivated at both $4^{\circ} \mathrm{C}$ and $15^{\circ} \mathrm{C}$ showed an exponential decrease with the age of the ice (Fig. 2). The viability of the analyzed bacterial communities showed a significant decrease with the ice age (Table 2); when cultivated at $4^{\circ} \mathrm{C}$, the highest viability was found in recent ice layers $(35 \%$ for $1-\mathrm{S}$ and $52 \%$ for $1-\mathrm{L})$, with a significant drop to $13 \%$ in $400 \mathrm{yr}-$ old ice, and as low as $2-5 \%$ in 900 yr-old ice. We found less viability of culturable bacteria when grown at $15^{\circ} \mathrm{C}$; varying from $10-19 \%$ in recent ice samples to $0.3-1.5 \%$ in both 400 and 900 yr-old ice, with the lowest cultured fraction found in 900-I sample (Table 2).

Table 2. Cell density of ice-contained microorganisms. The cell content of melted ice samples 1-S, 1-L, 400-O, 900-O and 900-I was determined by SYBR Green I staining using epifluorescence microscopy. The culturable cell density was measured by plating melted ice samples on R2B medium at 4 and $15^{\circ} \mathrm{C}$, respectively. The average values and standard deviations were calculated from 15 visual fields for ice-contained cells, and from triplicate data sets for cultured cells. Cell viability was expressed as percentage of cultured cells density relative to the total cell density.

\begin{tabular}{|c|c|c|c|c|c|}
\hline Sample & $\begin{array}{c}\text { Ice-contained } \\
\text { cell density } \\
\left(\text { cells mL } \mathrm{mL}^{-1}\right.\end{array}$ & $\begin{array}{c}\text { Cultured cell density } \\
\mathbf{4}^{\circ} \mathbf{C} \\
\left(\mathrm{CFU} \mathrm{mL}^{-1}\right)\end{array}$ & $\begin{array}{c}\text { Cell viability } \\
\mathbf{4}^{\circ} \mathbf{C} \\
(\%)\end{array}$ & $\begin{array}{c}\text { Cultured cell } \\
\text { density } \\
\mathbf{1 5}^{\circ} \mathbf{C} \\
\left(\mathrm{CFU} \mathrm{mL}^{-1}\right)\end{array}$ & $\begin{array}{c}\text { Cell viability } \\
\mathbf{1 5}^{\circ} \mathbf{C} \\
(\%)\end{array}$ \\
\hline $\mathbf{1 - S}$ & $(2.2 \pm 0.3) \times 105$ & $(7.8 \pm 1.4) \times 10^{4}$ & 35.0 & $(4.3 \pm 0.5) \times 10^{4}$ & 19.3 \\
\hline $\mathbf{1 - L}$ & $(1.0 \pm 0.3) \times 10^{5}$ & $(5.2 \pm 0.9) \times 10^{4}$ & 52.0 & $(1.0 \pm 0.2) \times 10^{4}$ & 10.0 \\
\hline $\mathbf{4 0 0 - 0}$ & $(2.9 \pm 0.9) \times 10^{5}$ & $(3.7 \pm 0.4) \times 10^{4}$ & 12.8 & $(4.4 \pm 0.8) \times 10^{3}$ & 1.5 \\
\hline $\mathbf{9 0 0 - 0}$ & $(2.9 \pm 0.3) \times 10^{4}$ & $(1.0 \pm 0.5) \times 10^{3}$ & 5.3 & $(4.0 \pm 0.9) \times 10^{2}$ & 1.4 \\
\hline $\mathbf{9 0 0 - I}$ & $(2.4 \pm 1.1) \times 10^{4}$ & $(0.5 \pm 0.3) \times 10^{3}$ & 2.1 & $(0.7 \pm 0.6) \times 10^{2}$ & 0.3 \\
\hline
\end{tabular}

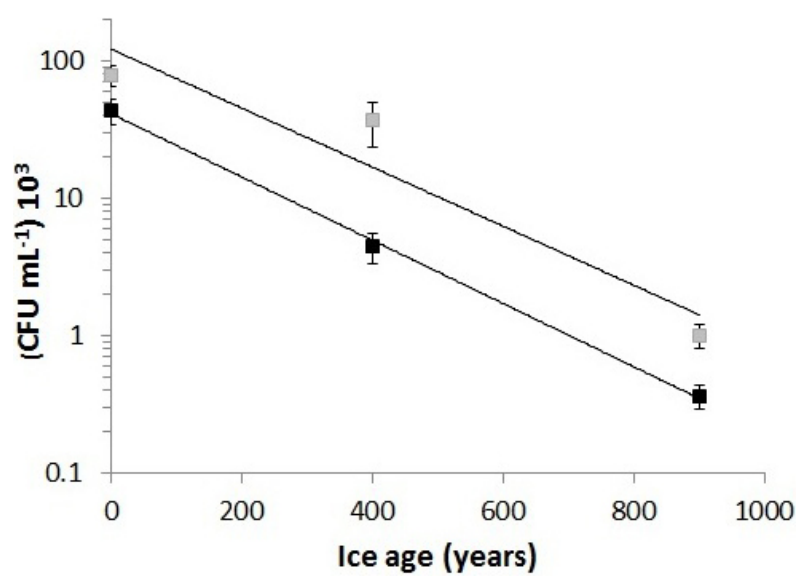

Fig. 2. Ice age dependence of cultured cell density. Cell density from each melted-ice sample cultivated on R2B-agar at $4^{\circ} \mathrm{C}$ (grey) and $15^{\circ} \mathrm{C}$ (black) was determined by serial dilution inoculations, as described in Methods. The cultured cell density (CFU mL-1) of 1-year and 900-years old ice-contained microbiota represent the average values (Table 2) for ice samples of same age, $1-\mathrm{S} / 1-\mathrm{L}$, and $900-\mathrm{O} / \mathrm{I}$, respectively. Curve plot at $4^{\circ} \mathrm{C}(\mathrm{R}=0.956) ; 15^{\circ} \mathrm{C}$ $(R=0.999)$. Two sample test provided a variance value of 0.55 .

\section{Liquid media growth of ice microbiota}

When the cave ice was cultivated for 20 days at $4^{\circ} \mathrm{C}$ and $15^{\circ} \mathrm{C}$ on various liquid media (T1, T2, LB and $\mathrm{LBG})$, differences in microbial diversity throughout the cave ice block became apparent (Bidle et al., 2007); at $4^{\circ} \mathrm{C}$ only media containing yeast extract (T2, LB and LBG) were suitable for the growth of cave-ice microorganisms, with the exception of the 1-S sample, while at $15^{\circ} \mathrm{C}$ all samples contained culturable bacteria on all media. In accordance with this, the calculated lag time and doubling time (Table 3 ) showed variations with cultivation temperature and media composition. At $4^{\circ} \mathrm{C}$, the lag time values varied from 4.4 to 10.9 days, with the exception of the 1-S sample cultivated on $\mathrm{T} 1$, which showed a delayed growth (13.4 days lag time). Under these conditions, the doubling time values ranged from 0.9 to 2.8 days. At $15^{\circ} \mathrm{C}$, growth started after only $0.1-1.7$ days (lag time), and the doubling time varied from 1 to 3.4 days.

\section{Community-level physiological profile (CLPP) of cave-ice microorganisms}

The calculated parameters AWCD, R, and $\mathrm{H}$ for the melted ice incubated at $15^{\circ} \mathrm{C}$ and $4^{\circ} \mathrm{C}$ using BIOLOG EcoPlates clearly indicated a higher functional diversity in 1-S and 400-O ice layers, corresponding to AWCD of $0.74 \pm 0.02$ and $0.94 \pm 0.09$, substrate richness $\mathrm{R}$ of $18.38 \pm 3.23$ and $24.08 \pm 1.44$, and 
Table 3. Growth parameters of cave ice microbiota cultivated at $4^{\circ} \mathrm{C}$ and $15^{\circ} \mathrm{C}$. (The doubling time (DT) and Lag time values were calculated from the corresponding growth curves, as indicated in Materials and Methods).

\begin{tabular}{|c|c|c|c|c|c|c|c|c|c|}
\hline \multirow{2}{*}{ Sample } & \multirow{2}{*}{$\begin{array}{c}\mathbf{T} \\
\left({ }^{\circ} \mathrm{C}\right)\end{array}$} & \multicolumn{2}{|c|}{ T1 } & \multicolumn{2}{|c|}{ T2 } & \multicolumn{2}{|c|}{ LB } & \multicolumn{2}{|c|}{ LBG } \\
\hline & & $\begin{array}{l}\text { DT } \\
\text { (day) }\end{array}$ & $\begin{array}{l}\text { Lag time } \\
\text { (day) }\end{array}$ & $\begin{array}{c}\mathbf{D T} \\
\text { (day) }\end{array}$ & $\begin{array}{l}\text { Lag time } \\
\text { (day) }\end{array}$ & $\begin{array}{c}\mathbf{D T} \\
\text { (day) }\end{array}$ & $\begin{array}{l}\text { Lag time } \\
\text { (day) }\end{array}$ & $\begin{array}{c}\text { DT } \\
\text { (day) }\end{array}$ & $\begin{array}{l}\text { Lag time } \\
\text { (day) }\end{array}$ \\
\hline $1-\mathrm{S}$ & & $3.06 \pm 0.01$ & $13.40 \pm 0.25$ & $0.91 \pm 0.14$ & $4.45 \pm 0.18$ & $1.22 \pm 0.01$ & $5.55 \pm 0.10$ & $1.26 \pm 0.05$ & $5.37 \pm 0.16$ \\
\hline $1-\mathrm{L}$ & & - & - & $1.19 \pm 0.10$ & $8.97 \pm 0.10$ & $1.49 \pm 0.03$ & $7.75 \pm 0.02$ & $1.96 \pm 0.14$ & $8.39 \pm 0.29$ \\
\hline $400-0$ & 4 & - & - & $2.00 \pm 0.05$ & $9.04 \pm 0.16$ & $2.77 \pm 0.01$ & $7.84 \pm 0.20$ & $2.16 \pm 0.02$ & $10.20 \pm 0.11$ \\
\hline $900-\mathrm{O}$ & & - & - & $1.81 \pm 0.06$ & $9.84 \pm 0.39$ & $1.99 \pm 0.10$ & $10.92 \pm 0.21$ & $2.00 \pm 0.03$ & $9.41 \pm 0.35$ \\
\hline 900-I & & - & - & $2.24 \pm 0.09$ & $7.95 \pm 0.15$ & $1.89 \pm 0.05$ & $7.24 \pm 0.24$ & $2.11 \pm 0.09$ & $7.31 \pm 0.30$ \\
\hline $1-\mathrm{S}$ & & $3.38 \pm 0.30$ & $0.59 \pm 0.11$ & $1.00 \pm 0.05$ & $0.96 \pm 0.01$ & $1.04 \pm 0.03$ & $1.66 \pm 0.03$ & $2.09 \pm 0.34$ & $1.20 \pm 0.23$ \\
\hline $1-\mathrm{L}$ & & $1.47 \pm 0.10$ & $1.70 \pm 0.02$ & $1.38 \pm 0.04$ & $1.56 \pm 0.12$ & $1.14 \pm 0.05$ & $0.25 \pm 0.05$ & $1.22 \pm 0.03$ & $0.21 \pm 0.04$ \\
\hline $400-0$ & 15 & $2.13 \pm 0.10$ & $0.45 \pm 0.08$ & $1.68 \pm 0.12$ & $0.36 \pm 0.07$ & $1.24 \pm 0.04$ & $0.33 \pm 0.08$ & $1.27 \pm 0.07$ & $0.61 \pm 0.03$ \\
\hline $900-0$ & & $1.50 \pm 0.04$ & $0.36 \pm 0.02$ & $1.20 \pm 0.03$ & $0.12 \pm 0.01$ & $\begin{array}{l}1.26 \pm 0.02 \\
3.18 \pm 0.05\end{array}$ & $\begin{array}{l}0.14 \pm 0.04 \\
1.60 \pm 0.37\end{array}$ & $1.74 \pm 0.15$ & $0.69 \pm 0.11$ \\
\hline 900-I & & $1.24 \pm 0.04$ & $0.61 \pm 0.09$ & $1.05 \pm 0.23$ & $1.75 \pm 0.14$ & $1.14 \pm 0.04$ & $0.77 \pm 0.19$ & $1.22 \pm 0.03$ & $0.46 \pm 0.11$ \\
\hline
\end{tabular}

Shannon-Weaver diversity index $\mathrm{H}$ of $2.55 \pm 0.02$ and $2.7 \pm 0.09$, respectively (Fig. 3). In the case of the 1-L and 900-O/I samples, the AWCD, R and H values showed a significant decrease (up to 20-fold). The lowest values were obtained for 900-I (AWCD of $0.04 \pm 0.01$ and $0.08 \pm 0.01, R$ of $1.04 \pm 0.62$ and 1.22 \pm 0.51 , and $\mathrm{H}$ of $0.18 \pm 0.01$ and $0.35 \pm 0.11$ ) at $15^{\circ} \mathrm{C}$ and $4^{\circ} \mathrm{C}$ temperature, respectively. All calculated parameters showed higher values for the microbial communities cultivated at $4^{\circ} \mathrm{C}$ as compared to $15^{\circ} \mathrm{C}$. Evenness $(\mathrm{E})$ values varied in the $0.88 \pm 0.05-0.97 \pm$ 0.12 interval, with lower average and higher standard deviation values for 900-O $(0.74 \pm 0.27)$ and 900-I $(0.84 \pm 0.12)$ samples cultivated at $4^{\circ} \mathrm{C}$.

The carbon substrate utilization profile of the Scărissoara cave ice bacterial communities (Supplemental Table 4) indicated the use of Tween 40 by all samples, regardless their growth temperature. Interestingly, the extensive use of this non-ionic detergent was also found in the cases of all analyzed strains belonging to Sphingomonas sp. isolated from lake sediments of southern Finland (Rapala et al., 2005). 1-S and 400-O microbiota could utilize most of the substrates (24 and 26, respectively), with some variations with the growth temperatures, while a more limited number of substrates was used by $1-\mathrm{L}$ (10) and 900-O/I (3/1).

Principal component analysis (PCA) of the BIOLOG EcoPlates variation in bacterial growth $\left(\mathrm{OD}_{595}\right)$ at $4^{\circ} \mathrm{C}$ and $15^{\circ} \mathrm{C}$ on 31 different C-sources (Fig. 4) explained $64.84 \%$ of the total variance (PC1). The ordination plot showed that the substrate utilization profiles of ice bacterial communities were location-specific; cultured bacteria from the 1-S and 400-O samples grown at $4^{\circ} \mathrm{C}$ and $15^{\circ} \mathrm{C}$ were distributed close to each other along $\mathrm{PC} 1$ axis, and distant from the other ice samples. The substrate utilization profiles of 900-O and 900-I samples formed a distinct group, in close proximity to the 1-L group, and independent of their growth temperature. Recent ice samples 1-S

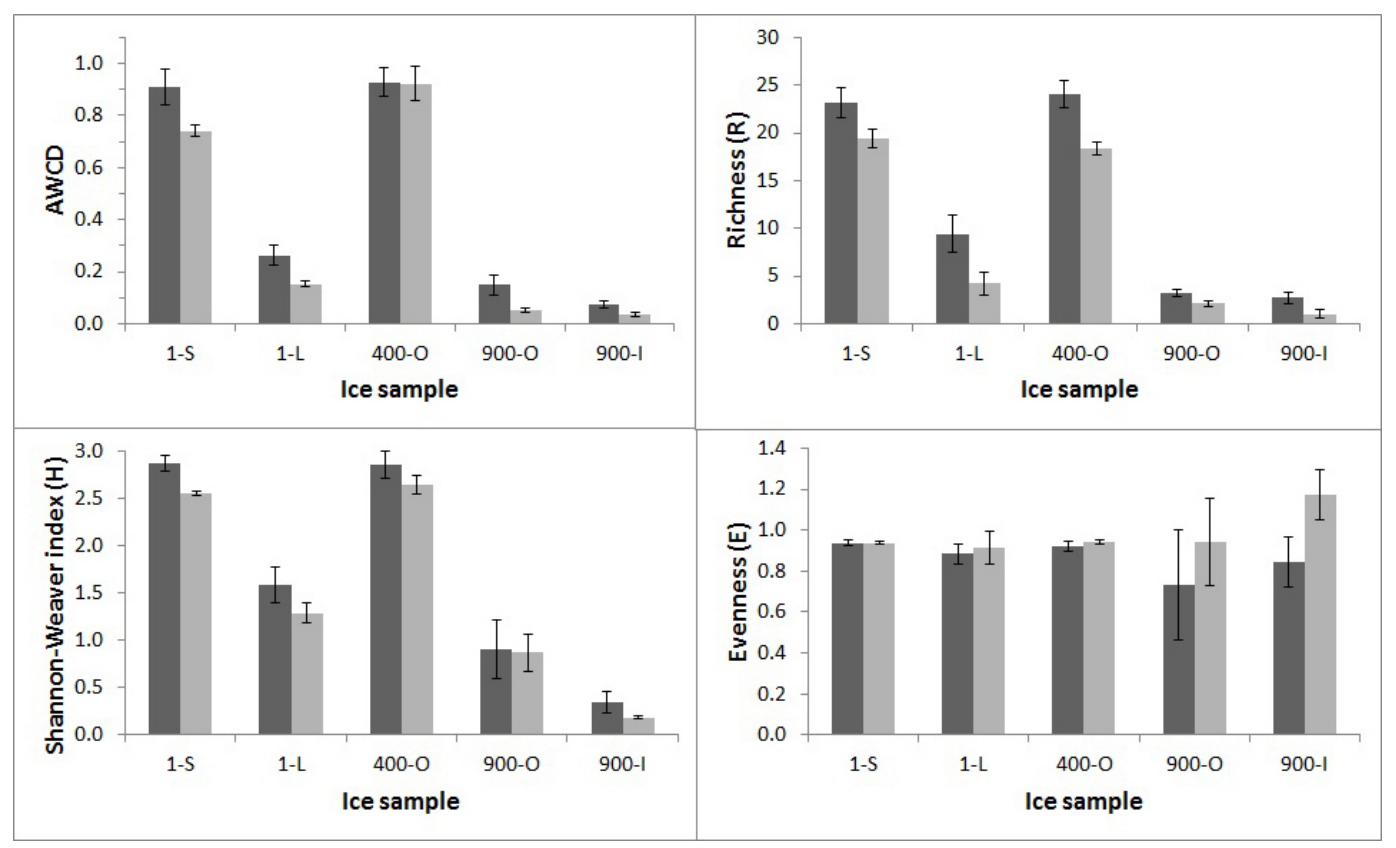

Fig. 3. BIOLOG EcoPlates carbon source usage by cave-ice microorganisms. EcoPlates inoculated with melted ice from samples 1-S, 1-L, 400-O, 900-O, 900-I were incubated at $4^{\circ} \mathrm{C}$ (dark grey) and $15^{\circ} \mathrm{C}$ (light grey), and the average well-color development (AWCD), richness $(R)$ and Shannon-Weaver index $(H)$ diversity parameters were calculated as indicated in Materials and Methods. The average and standard deviation values resulted from three different experiments. 


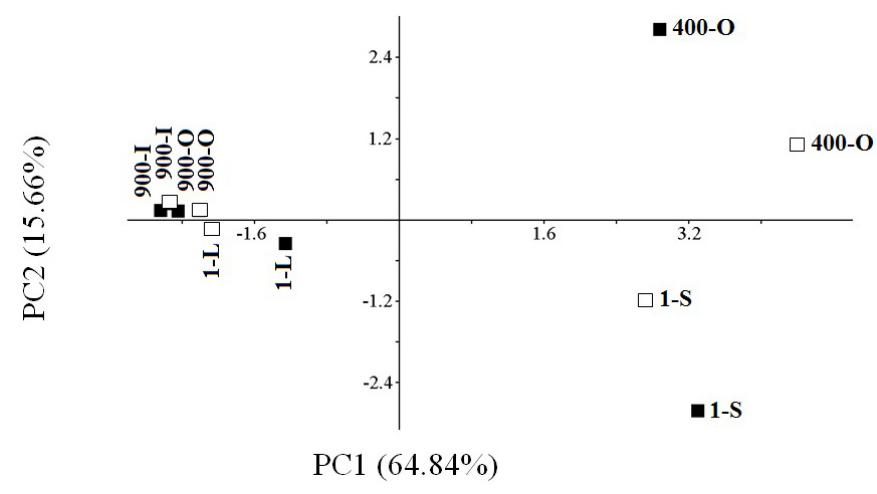

Fig. 4. PCA plot of BIOLOG EcoPlates distribution of ice samples based on C-source utilization. Melted ice samples 1-S, 1-L, 400-O, 900-O and 900-I were cultivated at $4^{\circ} \mathrm{C}(\square)$ and $15^{\circ} \mathrm{C}(\mathbf{\square})$ and the PCA distribution was carried out based on the microbial growth $\mathrm{OD}_{590}$ values.

and 1-L were separated along $\mathrm{PC} 2$ axis from the older (400-O and 900-O/I) ice layers. PC1 correlated ( $r=$ correlation coefficient) with specific C-sources, showing significant $(\mathrm{p}<0.05)$ positive correlation with the carbohydrates $D$-xylose $(r=0.32)$ and $D$-mannitol $(r=0.35)$, the carboxylic acid 4-hydroxy benzoic acid $(r=0.31)$, and aminoacids $L$-asparagine $(r=0.33)$ and $L$-serine $(r=0.39)$. In addition, PC2 correlated positively $(\mathrm{p}<0.05)$ with the carbohydrate $\alpha$ - $D$-lactose $(r=0.32)$ and carboxylic acid 4-hydroxy benzoic acid $(r=0.34)$, and negatively with both carbohydrates i-erythritol $(r=-0.44)$ and $D$-mannitol $(r=-0.44)$.

The PCA plot of the Shannon diversity index $(\mathrm{H})$ calculated for cultured bacteria at $4{ }^{\circ} \mathrm{C}$ and $15^{\circ} \mathrm{C}$, in relation with the physicochemical and chemical parameters of ice samples (Fig. 5), explained 93.4\% of the data variation for the separation on the first two axes. For the PC1 axis, all chemical parameters (Table 1) had approximately equal contribution to sample partition except for TC/TN, which had a large contribution to the sample separation along the PC2 axis. Therefore, sample 1-L showed a high score on PC2, being well separated from all other samples

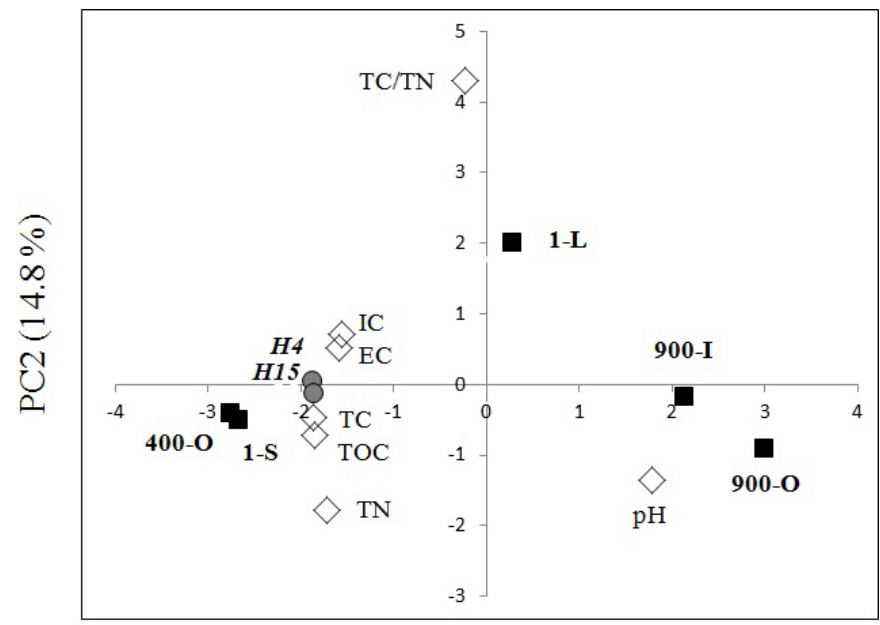

PC1 $(78.6 \%)$

Fig. 5. PCA biplot of environmental parameters and Shannon diversity index $(\mathrm{H})$ of cave-ice cultured microbiota. The average values (Table 1) of pH, EC, TC, TOC, IC, TN and TC/TN (physico)chemical parameters $(\diamond)$ and calculated $\mathrm{H}$ index when cultivated at $4^{\circ} \mathrm{C}(\bullet \mathrm{H} 4)$ and $15^{\circ} \mathrm{C}(\bullet \mathrm{H} 15)$ using the BIOLOG EcoPlates system were used for the analysis of the 1-S, 1-L, 400-O, 900-O and 900-I ice samples (匹). Correlation coefficient $(r)$ values varied in the $\pm(0.663-0.998)$ interval, with $p$-values $<0.044$. based on the TC/TN contribution. Samples 1-S and 400-O formed a separate group based on similar physicochemical characteristics. The oldest ice samples, 900-O and 900-I, were also grouped due to the $\mathrm{pH}$ of the ice substrate, which was more alkaline (Table 1). The Shannon-Weaver diversity $\mathrm{H}$ index of microbial communities grown at high $\left(\mathrm{H}^{15}\right)$ and low $\left(\mathrm{H}^{4}\right)$ temperatures appeared to be explained by EC $(\mathrm{p}<0.04)$, TOC $(\mathrm{p}<0.01)$ and IC $(\mathrm{p}<0.03)$ carbon contents, and showed significant $(\mathrm{p}<0.01)$ negative correlation with the $\mathrm{pH}$.

\section{PCR-DGGE and phylogenetic composition of ice bacterial community}

The DGGE profile of PCR-amplified bacterial 16S rRNA gene fragments of ice microbial communities cultivated in different media at low and high temperatures (Fig. 6) indicated the presence of different species in all five samples. The distinct DGGE patterns of bacterial amplicons from T1, T2, LB and LBG cultures at $4^{\circ} \mathrm{C}$ (Fig. 6A) and $15^{\circ} \mathrm{C}$ (Fig. 6B) confirmed the diversity of culturable bacterial communities from each ice sample and their distinctiveness across the cave ice block. A total of 77 DGGE amplicons (Fig. 6) of cultured bacteria at $4^{\circ} \mathrm{C}(37)$ and $15^{\circ} \mathrm{C}(40)$ were excised from the gels, reamplified and sequenced, corresponding to 68 distinct bacterial OTUs showing 86-100\% identity with environmental sequences (Supplemental Table 5). The closest identity to 18 OTUs originated from cold environments (glaciers, snow pits, ice nuclei, permafrost, Arctic and Antarctic soil, lake sediments, mats, etc.), with 3 from cave-related habitats (lava cave, cave drip water, and karst water rivulet), while 40 others OTUs corresponded to sequences from soil, dust and sand, ground water, coastal and deep sea sediments, rivers and streams, sea and lakes water, biofilms and sediments, thermal springs, etc. (Supplemental Table 5).

Eight bacterial OTUs were conserved among ice layers of different age and/or sediment content and demonstrated homology to Pseudomonas, Serratia, and Rahnella species, and uncultured clones (Supplemental Table 5). A soil bacterium 5V-07 [EU839205] homolog was found in 1-S and 900-O/I ice samples (SM4.1-S.46, SM15.900-O.84 and SM15.900-I.99) was cultivated at $4^{\circ} \mathrm{C}$ and $15^{\circ} \mathrm{C}$, respectively. Also, two ice cave OTUs homologous to Pseudomonas sp. [FM161544] (SM15.1-S.93 and SM15.900-I.102) and Rahnella sp. [FM161540] (SM15.400-O.96 and SM15.900-O.98), were common to different aged ice layers (Supplemental Table 5). A glacier isolated Serratia sp. [LN680099] homolog was found in both 1-S and 900-O samples (SM15.1-S.80 and SM15.900-O.74) cultivated at $15^{\circ} \mathrm{C}$. Recent (SM4.1-L.43) and $900 \mathrm{yr}-$ old (SM15.900-I.101) clear ice samples contained a homologue of an Arctic thermal spring uncultured clone [JX257866]. The deep sea sediment homologue Pseudomonas sp. [AM111029] was encountered in both SM4.1-S.1 and SM15.900-I.64. In addition to various aged strata, common OTUs were also found in organic rich and clear ice samples of same age (SM4.900-O.10 and SM4.900-I.13), and in the recent ice samples SM4.1-S.37/44) (Supplemental Table 5, Fig. 6). 
The similar migration pattern of several DGGE amplicons (Fig. 6) suggested the occurrence of additional bacterial strains common to different cave ice layers, such as the soil bacterium 5V-07 [EU839205], which was present in four of the five analyzed samples (1-S, 400-O and 900-O/I), while Pedobacter steynii [KF583713] (1-L/400-O), Bacillus sp. [KC160801] (1-L/400-O), bacterial clone VS1638 [JX257866] homologue (1-S/900-I), Pseudomonas clone [AY881672] (400-O/900-I), and uncultured bacterium [FJ527575] (1-S/900-O) could be identified in two different aged ice samples.

The relative abundance of the identified OTUs in Scărişoara ice samples (Fig. 7) highlighted the composition heterogeneity of culturable bacterial communities throughout the cave's ice block, indicating the ubiquitous presence of Gammaproteobacteria that dominated 1-S and 900-O/I ice layers, and of Firmicutes that was less represented, but with a major presence in 400O. Bacteroidetes phylum was encountered only in 1-L and 900-O/I samples. Moreover, 1-L sample appeared to contain a higher number of taxa, comprising Actinobacteria and Betaproteobacteria in addition to Gammaproteobacteria, Firmicutes, and Bacteroidetes.

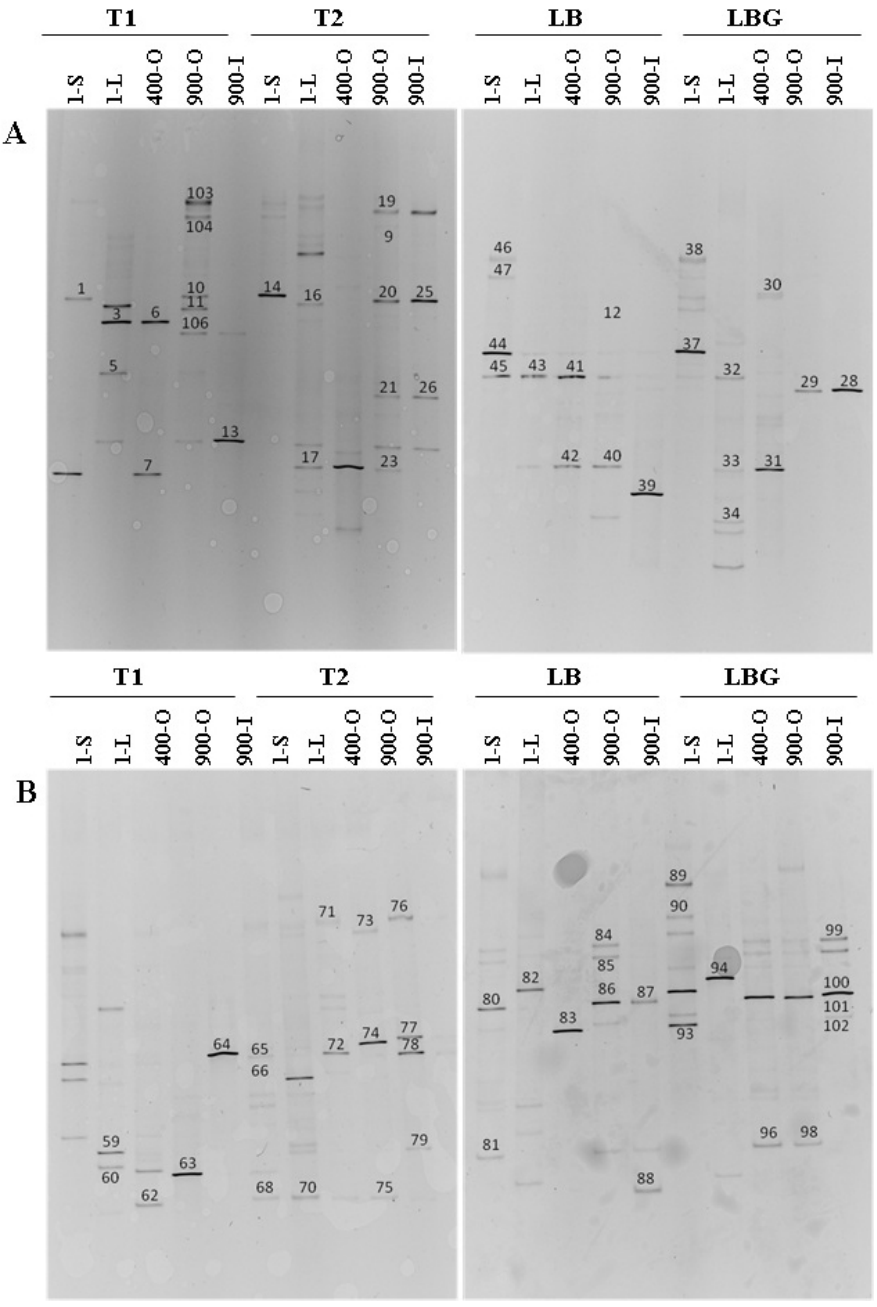

Fig. 6. DGGE profiles of ice-contained bacterial 16S rRNA gene fragments. Bacterial $16 \mathrm{~S}$ rDNA amplicons of total DNA extracted from T1, T2, LB and LBG cultures (A) at $4^{\circ} \mathrm{C}$ and (B) at $15^{\circ} \mathrm{C}$ were analyzed by DGGE using a $30-55 \%$ denaturant gradient, as indicated in Methods. The amplicon number of sequenced DNA fragments is also indicated.

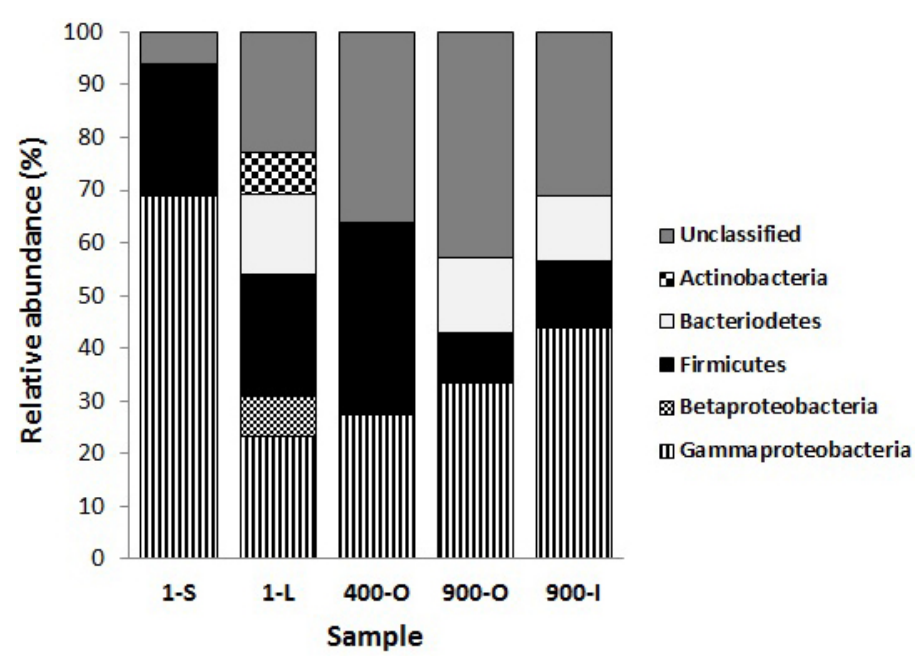

Fig. 7. Relative abundance of cultured bacterial clades from ice samples. The affiliation of bacterial 16S rDNA OTUs identified in the cultivated ice samples was determined based on their closest-relative affiliation (Supplemental Table 5).

\section{DISCUSSION}

Our investigation revealed the presence of culturable bacteria in all analyzed samples of Scărişoara Cave ice block up to 900 yr-old, varying in the range of 5 $\mathrm{x} 10^{2}-7.8 \times 10^{4} \mathrm{CFU} \mathrm{mL}^{-1}$, similar to other glacial habitats (Skidmore et al., 2000; Lee at al., 2011; Bell, 2012). The viability of cultured bacteria, as compared to the total cell content $\left(2.2 \times 10^{4}-2.9 \times 10^{5}\right.$ cell $\left.\mathrm{mL}^{-1}\right)$, showed a remarkable drop in older ice strata, shifting from $35-52 \%$ culturability in recent ice to $0.3-5.3 \%$ in the 900 yr-old ice samples.

Cultivation in the presence of different substrates and at different temperatures revealed a various response in terms of growth lag time and doubling time of bacterial communities from all analyzed ice samples, demonstrating their compositional heterogeneity. The abundance of the cultured cave ice-contained bacteria appeared to be influenced by the age and physicochemical properties of the ice substrate, with a lesser impact of ice chemistry (carbon and nitrogen contents).

The cell density of culturable microbiota decreased exponentially with the age of the ice layer. The recent ice samples 1-S and 1-L exhibited the highest cell content when cultivated on R2A at low and high temperatures, while the lowest viable cell content was found in 900 yr-old ice. The viability of cells cultivated at $4^{\circ} \mathrm{C}$ was generally higher than that at $15^{\circ} \mathrm{C}$ in all the analyzed ice samples, suggesting a higher resilience of cold-adapted microorganisms in this habitat. A significant difference between bacterial communities cultured at $4^{\circ} \mathrm{C}$ and $15^{\circ} \mathrm{C}$ was observed in 400 yr-old ice, favoring low-temperature culturable microbiota.

Physicochemical parameters of the ice samples appear to have a strong effect on the culturable bacterial cell content of this habitat. The high cell density of heterotrophs from the sedimentrich ice samples $1-\mathrm{S}$ and 400-O suggested that the activity and survival of cells embedded in cave-ice was influenced by the high sediment content and TDS content of the ice layers. No clear dependence of the cell content and functional variability of the 
samples on the ice chemical characteristics was observed; the recent ice samples $1-\mathrm{S}$ and $1-\mathrm{L}$ showed a comparable culturability, despite of different TOC and TN concentrations and utilized carbon-sources (BIOLOG EcoPlates). Considering the similarities of 1-S and 400-O ice formation (Perşoiu \& Pazdur, 2011), this quantitative characteristic of cave-ice bacterial communities could be strongly related to the physicochemical characteristics of the cave ice layers. In the case of the common-origin ice layers 900-O and 900-I, both the chemical properties and cultured microbial contents do not showed significant variations, confirming a strong correlation of the bacterial content mainly with the ice age.

The $\mathrm{C} / \mathrm{N}$ composition of the ice sediments varied considerably with the distance from the cave entrance. The distinct ice formation pattern of 1-S and 1-L samples, corresponding to surface-enriched organic sediments, and cryogenic cave carbonate enriched ice, respectively, was reflected in the total and organic/inorganic carbon and nitrogen contents of the two recent ice samples. Thus, the higher TOC and TN contents of $1-\mathrm{S}$ could originate from both the direct influx of surface-derived organic matter, due to the proximity of the site to cave entrance, and from the activity and decomposition of phototrophs flourishing in the sunlit supraglacial lake formed during the warm period (data not shown). Surprisingly, the inorganic carbon (IC) content of the two surface samples 1-S and $1-\mathrm{L}$ was similar, indicating that the variations of dissolved carbonate and cryogenic cave carbonates formed in the two locations (Zak et al., 2008; Perşoiu et al., 2011b) were removed in the supraglacial lake, with little or no contribution from bacteria to the calcification process.

As shown by Perşoiu \& Pazdur (2011), the ice formed near the cave entrance (sample 1-S, Fig. 1A) was rich in surface-originating materials (Feurdean et al., 2011), while that in the central part of the Great Hall (sample 1-L, Fig. 1A) contains mainly autogenic material composed of cryogenic cave carbonates and carbonates derived from the weathering of the cave walls (Zak et al., 2008).

In addition, climate at the time of ice layers formation appeared to play a role in geochemical composition of ice strata, and influence the culturable fraction of embedded bacterial communities. Thus, the climate associated to sample 900-O formation ( 1050 AD, the peak of the Medieval Warm Period - MWP) was slightly warmer and drier than during the genesis of $400-O$ sample $(\sim 1550 \mathrm{AD}$, during the colder and wetter Little Ice Age - LIA). These climatic differences implied changes in the forest composition above the cave, with dominance of beech (Fagus sylvatica) during MWP, and of spruce (Picea abies) during the LIA, respectively (Feurdean et al., 2011). The high TOC and TN contents of the 400-O ice sample relative to $900-\mathrm{O}$ could be related to the enrichment in carbon and nitrogen of the cave-surrounding soil formed during spruce-dominated forests period (LIA), as compared to the one formed during beech-dominated forests period (MWP) (Vesterdal et al., 2008).
The functional heterogeneity of cultured ice bacteria throughout the cave ice block was revealed by the various responses in terms of growth lag time and doubling time when cultivated at $4^{\circ} \mathrm{C}$ and $15^{\circ} \mathrm{C}$ on different substrates. The CLPP analysis using BIOLOG EcoPlates revealed an overall higher functional diversity of cold-active bacteria throughout the cave ice block, based on higher $\mathrm{H}$ values when cultivated at $4^{\circ} \mathrm{C}$. Except for the general use of Tween 40 by all analyzed samples of the cave ice block (Rapala et al., 2005), the carbon-source utilization varied with the age and sediment content of the ice substrate. The functional heterogeneity estimated by BIOLOG EcoPlates cultivation showed a relatively grouped PCA distribution of ice bacterial communities based on the age of the ice, which was independent of their sediment content (900-O and 900-I samples) and light regime (1-S and 1-L samples). In the case of $1-\mathrm{S}$ and 400-O samples, a correlation of cultured bacterial composition and functional heterogeneity with the physicochemical properties of the ice layers could be observed, in direct correlation with their relatively grouped PCA distribution.

In addition, the bacterial functional diversity of the cultured segment of ice microbiota appeared to be dependent also on the origins of water source that formed the different areas of Scărişoara ice block, as indicated by the large shift (2-5-fold reduction) of the $\mathrm{H}$ values of the $1-\mathrm{S}$ vs.1-L and $400-\mathrm{O}$ vs. 900O samples, respectively, and their PCA distribution associated to the physicochemical parameters. Meanwhile, the ice samples of a high sediment-content (1-S, 400-O and 900-O) were characterized by the same TC/TN ratio, but had different cell numbers and culturable bacteria substantiating a moderate impact of the cave-ice chemistry on the microbial community structure from Scărişoara ice block. This culturable ice-embedded microbiota appears to be dependent in particular on the age and physicochemical properties of the ice substrate.

The 77 identified bacterial sequences in cultured ice samples up to 900 years old were assigned to various species of Pseudomonas, Carnobacterium Rahnella, Bacillus, Paenibacillus, Lysinibacillus, Sporosarcina, Flavobacterium, Pedobacter, Arthrobacter, Serratia, Yersinia, and unspecified uncultured bacteria. These strains were affiliated to Proteobacteria, Bacteroidetes, Firmicutes, and Actinobacteria phyla, dominated by Gammaproteobacteria. Common bacterial strains with those described in various cold habitats (Segawa et al., 2010; Margesin \& Miteva, 2011; Wong et al., 2011; Anesio \& Laybourn-Parry, 2012) were found in Scărişoara cave ice block, confirming a common distribution of specific strains in glacial environments. Among these, the Arthrobacter strain SM4.1-L.33 [KF853212] identified in recent ice deposits (1-L sample) of Scărişoara cave and grown at $4{ }^{\circ} \mathrm{C}$ corresponded ( $97 \%$ identity) to a strain isolated from a 25,000 years old permafrost ice wedge (Katayama et al., 2007). Facultative psychrophilic species belonging to this genus (Arthrobacter psychrophenolicus) have also been identified in an Austrian alpine ice cave (Margesin et al., 2004). 
Interestingly, the presence in old ice strata (400$\mathrm{O}$ and 900-O) of a karst water-specific Rahnella species, an endophytic bacteria from spruce (Picea abies) seeds (Cankar et al., 2006), provides a putative microbial biomarker candidate for distinguishing between the two periods based on the quantitative representation of this bacterium in ice layers from dominating (LIA) or scarcer (WMP) spruce forests occurring in the surroundings of the cave at the time of the ice deposition (Feurdean et al., 2011). However, quantitative analysis of both Rahnella representation as well as climate and vegetation dynamics outside the cave is required in order to confirm this hypothesis. Another cave-associated bacterium was the cultured strain SM15.400-O.62 [KJ454424] from 400-O ice sample, homologous (99\% identity) to a lava-cave bacterium clone, indicating the presence of specific bacteria for cave environments.

Conservation of bacterial species in increasing aged ice sediments, most of them as culturable organisms, was confirmed in the cases of different OTUs belonging to particular Pseudomonas and Paenibacillus genera, and uncultured bacteria from soil and Arctic thermal springs.

In addition to the identified cultured phylotypes, the high ratio (28.2\% average value) of unclassified bacterial OTUs found in Scărişoara Cave ice block, reaching $42.8 \%$ in the case of $400-O$ sample, suggested a higher bacterial diversity of the cave ice microbiota. Also, the low identity score (86-96\%) of several cultured ice bacterial sequences suggest the ability to identify novel species in this glacial habitat. Further investigations of environmental samples should provide a more accurate overview of the cave ice-microbiota, overcoming the limitations induced by cultivation and PCR amplification, and revealing also the autotrophic bacterial communities that are expected to be prominent in this type of habitat.

This first report on the time and space-dependence of cultured bacterial communities from a perennial cave ice block and continues to contribute to the characterization of Scărişoara Ice Cave, which is already well-documented glacial habitat from geological and palaeoclimatic perspectives (Racoviță \& Onac, 2000; Perşoiu \& Pazdur, 2011). By identifying bacterial species, and highlighting differences on the abundance, distribution, and diversity of the cave ice block-embedded bacterial communities for the last millennium, our data support the hypothesis of a close relationship between climatic-related source microbiota and the cave-ice bacterial community composition, allowing for identifying possible climate biomarkers in this underground glacial habitat.

\section{AKNOWLEDGMENTS}

We are grateful to Bogdan P. Onac for constructive scientific discussions and technical assistance during field trips, to Dr. Alina Vasilescu (International Centre of Biodynamics Bucharest) and Drd. Larisa Florescu (Institute of Biology Bucharest) for precious help with the statistical analyses, and to Christian A. Ciubotărescu ("Sfinx" Speleological Association
Garda) for speleological support. We thank Vlad Murariu (Heavy Duties, Cluj Napoca, Romania) for manufacturing the ice coring drill, and the Apuseni Natural Park Administration and the Commission of Speleological Patrimony, Romania, for granting permissions for sampling in Scărişoara Ice Cave. This study was supported by the PN-II-ID-PCE-2011 -3-0742 grant (contract nr. 159/28.10.2011, ANCSUEFISCDI Romania), and RO1567-IBB05/2016 of the Romanian Academy.

\section{REFERENCES}

Adams H.E., Crump B.C. \& Kling G.W., 2014 Metacommunity dynamics of bacteria in an arctic lake: the impact of species sorting and mass effects on bacterial production and biogeography. Frontiers in Microbiology, 5: 1-10.

http://dx.doi.org/10.3389/fmicb.2014.00082

Altschul S.F., Madden T.L., Schäffer A.A., Zhang J., Zhang Z., Miller W. \& Lipman D.J., 1997 - Gapped BLAST and PSI-BLAST: a new generation of protein database search programs. Nucleic Acids Research. 25: 3389-3402.

http://dx.doi.org/10.1093/nar/25.17.3389

Anesio A.M. \& Laybourn-Parry J., 2012 - Glaciers and ice sheets as a biome. Trends in Ecology \& Evolution, 27: 219-225.

http://dx.doi.org/10.1016/j.tree.2011.09.012

Bell E.M. (Ed.), 2012 - Life at Extremes: Environments, Organisms, and Strategies for Survival. CABI, Wallingford, Oxfordshire, 554 p. http://dx.doi.org/10.1079/9781845938147.0000

Bidle K.D., Lee S., Marchant D.R. \& Falkowski P.G., 2007 - Fossil genes and microbes in the oldest ice on earth. Proceedings of the National Academy of Sciences USA, 104: 13455-13460.

http://dx.doi.org/10.1073/pnas.0702196104

Cankar K., Kraigher H., Ravnikar M. \& Rupnik M., 2006 - Bacterial endophytes from seeds of Norway spruce (Picea abies L. Karst). FEMS Microbiology Letters, 244: 341-345.

http://dx.doi.org/10.1016/j.femsle.2005.02.008

Castresana J., 2000 - Selection of conserved blocks from multiple alignments for their use in phylogenetic analysis. Molecular Biology and Evolution, 17: 540-552.

http://dx.doi.org/10.1093/oxfordjournals.molbev.a026334

Chevenet F., Brun C., Banuls A.L., Jacq B. \& Christen R., 2006 - TreeDyn: towards dynamic graphics and annotations for analyses of trees. BMC Bioinformatics, 7:439-448.

http://dx.doi.org/10.1186/1471-2105-7-439

Clarke K.R., 1993 - Non-parametric multivariate analyses of changes in community structure. Australian Journal of Ecology, 18: 117-143. http://dx.doi.org/10.1111/j.1442-9993.1993.tb00438.x

Deming J.W., 2002 - Psychrophiles and Polar regions. Current Opinion in Microbiology, 5: 301-309. http://dx.doi.org/10.1016/S1369-5274(02)00329-6

Dieser M., Nocker A., Priscu J.C. \& Foreman C.M., 2010 - Viable microbes in ice: application of molecular assays to McMurdo Dry Valley lake ice communities. Antarctic Science, 22: 470-476.

http://dx.doi.org/10.1017/S0954102010000404

Edgar R.C., 2004 - MUSCLE: multiple sequence alignment with high accuracy and high throughput. Nucleic Acids Research, 32:1792-1797. http://dx.doi.org/10.1093/nar/gkh340 
Feurdean A., Perşoiu A., Pazdur A. \& Onac B.P., 2011 - Evaluating the palaeoecological potential of pollen recovered from ice in caves: a case study from Scărişoara Ice Cave, Romania. Review of Palaeobotany and Palynology, 165: 1-10.

http://dx.doi.org/10.1016/j.revpalbo.2011.01.007

Felip M., Sattler B., Psenner R. \& Catalan J., 1995 Highly-active microbial communities in the ice and snow cover of high-mountain lakes. Applied Environmental Microbiology, 61: 2394-2401.

Garland J.L., 1997 - Analysis and interpretation of community-level physiological profiles in microbial ecology. FEMS Microbiology Ecology, 24: 289-300.

http://dx.doi.org/10.1111/j.1574-6941.1997.tb00446.x

Garland J.L. \& Mills A.L., 1991 - Classification and characterization of heterotrophic microbial communities on the basis of patterns of community level solecarbon-source utilization. Applied and Environmental Microbiology, 57: 2351-2359.

Guindon S. \& Gascuel O., 2003 - PhyML: A simple, fast, and accurate algorithm to estimate large phylogenies by maximum likelihood. Systematic Biology, 52: 696-704. http://dx.doi.org/10.1080/10635150390235520

Gunde-Cimerman N., Wagner D. \& Häggblom M., 2012 - Polar and alpine microbiology. FEMS Microbiology Ecology, 82: 215-216.

http:/ /dx.doi.org/10.1111/1574-6941.12004

Hall T., 2007 - BioEdit: Biological sequence alignment editor for Win95/98/NT/2K/XP. Carlsbad, CA: Ibis Biosciences. http://www.mbio.ncsu.edu/BioEdit/bioedit.html

Hillebrand-Voiculescu A., Rusu A., Itcus C., Perşoiu A., Brad T., Pascu D., Ardelean I., Onac B.P. \& Purcarea C., 2013 - Bacterial 16S rRNA gene clone library from recent ice stalagmites of Scărişoara cave. Romanian Journal of Biochemistry, 50: 109-118.

Hillebrand-Voiculescu A., Itcus C., Ardelean I., Pascu M.D., Perşoiu A., Rusu A., Brad T., Popa E., Onac B.P. \& Purcarea C., 2014 - Searching for cold-adapted microorganisms in the underground glacier of Scărişoara ice cave, Romania. Acta Carsological, 43: 319-329.

Holmlund P., Onac B.P., Hansson M., Holmgren K., Morth M., Nyman M., \& Perşoiu A., 2005 - Assessing the paleoclimate potential of cave glaciers: The example of the Scărişoara Ice Cave (Romania). Geography Annals, A87: 193-201.

http://dx.doi.org/10.1111/j.0435-3676.2005.00252.x

Insam H. \& Goberna M., 2004 - Use of Biolog ${ }^{\circledR}$ for Community Level Physiological Profiling (CLPP) of Environmental Samples. Molecular Microbial Ecology Manual, (2 ${ }^{\text {nd }}$ ed.). Kluwer Academic: Dordrecht, The Netherlands. p. 853-860.

Katayama T., Tanaka M., Moriizumi J., Nakamura T., Brouchkov A., Douglas T.A., Fukuda M., Tomita F. \& Asano K., 2007 - Phylogenetic analysis of bacteria preserved in a permafrost ice wedge for 25,000 years. Applied and Environmental Microbiology, 73: 2360-2363. http://dx.doi.org/10.1128/AEM.01715-06

Kemple W.G., Sadler P.M. \& Strauss D.J., 1989 - A prototype constrained optimization solution to the time correlation problem. In: Statistical Applications in the Earth Sciences, Agterberg F.P. \& Bonham-Carter G.F. (Eds.), Geological Survey of Canada. Paper 89-9. p. 417-425.

Lanoil B., Skidmore M., Priscu J.C., Han S., Foo W., Vogel S.W., Tulaczyk S. \& Engelhardt H., 2009 - Bacteria beneath the West Antarctic ice sheet. Environmental Microbiology, 11: 609-615.

http://dx.doi.org/10.1111/j.1462-2920.2008.01831.x
Lapanje A., Wimmersberger C., Furrer G., Brunner I. \& Frey B. 2012 - Pattern of elemental release during the granite dissolution can be changed by aerobic heterotrophic bacterial strains isolated from Damma Glacier (central Alps) deglaciated granite sand. Microbial Ecology, 63: 865-882. http://dx.doi.org/10.1007/s00248-011-9976-7

Lauriol B., Prevost C. \& Lacelle D., 2006 - The distribution of diatom flora in ice caves of the northern Yukon Territory, Canada: relationship to air circulation and freezing. International Journal of Speleology, 35: 83-92. http://dx.doi.org/10.5038/1827-806X.35.2.4

Lee Y.M., Kim S.Y., Jung J., Kim E.H., Cho K.H., Schinner F., Margesin R., Hong S.G. \& Lee H.K., 2011 - Cultured bacterial diversity and human impact on alpine glacier cryoconite. Journal of Microbiology, 49: 355-362.

http://dx.doi.org/10.1007/s12275-011-0232-0

Lehman R.M., Colwell F.S., Ringelbergb D.B. \& Whiteb D.C., 1995 - Combined microbial community level analyses for quality assurance of terrestrial subsurface cores. Journal of Microbiological Methods, 22: $263-281$

http://dx.doi.org/10.1016/0167-7012(95)00012-A

Margesin R., Schumann P., Sproer C. \& Gounot A.M., 2004 - Arthrobacter psychrophenolicus sp. nov., isolated from an alpine ice cave. International Journal of Systematic and Evolutionary Microbiology, 54: 2067-2072.

http://dx.doi.org/10.1099/ijs.0.63124-0

Margesin R. \& Miteva V.I., 2011 - Diversity and ecology of psychrophilic microorganisms. Research in Microbiology, 162: 346-361.

http://dx.doi.org/10.1016/j.resmic.2010.12.004

Miteva V.I., Sheridan P.P. \& Brenchley J.E., 2004 Phylogenetic and Physiological Diversity of Microorganisms Isolated from a Deep Greenland Glacier Ice Core. Applied and Environmental Microbiology, 70: 202-213.

http://dx.doi.org/10.1128/AEM.70.1.202-213.2004

Murray A.E., Kenig F., Fritsen C.H., Mckay C.P., Cawleyd K.M., Edwards R., Kuhn E., Mcknight D.M., Ostrom N.E., Peng V., Poncea A., Priscu J.C., Samarkin V., Townsend A.T., Wagh P., Young S.A., Yung P.T. \& Doran P.T., 2012 - Microbial Life at $-13^{\circ} \mathrm{C}$ in the brine of an ice-sealed Antarctic lake. Proceedings of the National Academy of Sciences USA, 109: 20626-20631.

http://dx.doi.org/10.1073/pnas. 1208607109

Muyzer G., De Waal E.C. \& Uitterlinden A.G., 1993 Profiling of complex microbial populations by denaturing gradient gel electrophoresis analysis of polymerase chain reaction-amplified genes coding for 16S rRNA. Applied and Environmental Microbiology, 59: 695-700.

Noble R.T \& Fuhrman J.A., 1998 - Use of SYBR Green I for rapid epifluorescence counts of marine viruses and bacteria. Aquatic Microbial Ecology, 14: 113-118. http://dx.doi.org/10.3354/ame014113

Onac B.P., Perşoiu A., Racoviță G., Tamas T. \& Viehmann I., 2007 - Scărişoara. Studia, Cluj, 84 p.

Perşoiu A., Onac B.P., Wynn J.G., Bojar A.V., Holmgren K., 2011a - Stable isotope behavior during cave ice formation by water freezing in Scărişoara Ice Cave, Romania. Journal of Geophysical Research, Atmosphere, 116: D02111.

http://dx.doi.org/ 10.1029/2010JD014477

Perşoiu A., Onac B.P., Perşoiu I., 2011b - The interplay between air temperature and ice mass balance changes in Scărişoara ice cave, Romania. Acta Carstologica, 40: 445-456. 
Perşoiu A., Pazdur A., 2011 - Ice genesis and its long-term mass balance and dynamics in Scărişoara Ice Cave, Romania. The Cryosphere, 5: 45-53. http://dx.doi.org/10.5194/tc-5-45-2011

Pessi I.S., Elias Sde O., Simões F.L., Simões J.C. \& Macedo A.J., 2012 - Functional diversity of microbial communities in soils in the vicinity of Wanda Glacier, Antarctic Peninsula. Microbes and Environments, 27: 200-203.

http://dx.doi.org/10.1264/jsme2.ME11311

Pop E., 1949 - Bacterii nitrificante in pestera dela Scărişoara. Buletin Ştiințific, 1: 901-907.

Price P.B., 2007 - Microbial life in glacial ice and implications for a cold origin of life. FEMS Microbiology and Ecology, 59: 217-231.

http://dx.doi.org/10.1111/j.1574-6941.2006.00234.x

Priscu J.C., Fritsen C.H., Adams E.E., Giovannoni S.J., Paerl H.W., McKay C.P., Doran P.T., Gordon D.A., Lanoil B.D. \& Pinckney J.L., 1998 - Perennial Antarctic lake ice: an oasis for life in a Polar desert. Science, 280: 2095-2098.

http://dx.doi.org/10.1126/science.280.5372.2095

Priscu J.C., Christner B.C., Foreman C.M. \& RoystonBishop G., 2007 - Biological material in ice cores. Elias SA (Ed.) Encyclopedia of Quaternary science, Elsevier, Amsterdam, p. 1156-1167.

Racoviță E.G., 1927 - Observations sur la glaciere naturelle dite "Ghețarul de la Scărişoara". Bulletin de la Société des Sciences de Cluj, 3: 75-108.

Racovitza G., 1994 - Bilan climatique de la grotte glacière de Scărişoara (Monts du Bihor, Roumanie), dressé sur dix années d'observations. Travaux de l'Institut de Spéologie "E. Racovitza”, 33: 107-158.

Racoviță G. \& Onac B.P., 2000 - Scărişoara Glacier Cave. Monographic study. Ed. Carpatica, Cluj-Napoca, Romania. 140 p.

Rapala J., Berg K.A., Lyra C., Niemi R.M., Manz W., Suomalainen S., Paulin L. \& Lahti K., 2005 - Paucibacter toxinivorans gen. nov., sp. nov., a bacterium that degrades cyclic cyanobacterial hepatotoxins microcystins and nodularin. International Journal of Systematic and Evolutionary Microbiology, 55: 1563-1568. http://dx.doi.org/10.1099/ijs.0.63599-0

Reasoner D.J. \& Geldreich E.E., 1985 - A new medium for the enumeration and subculture of bacteriafrom potable water. Applied and Environmental Microbiology, 49: 1-7.

Rehakova K., Stibal M., Sabacka M. \& Rehak J., 2010 Survival and colonisation potential of photoautotrophic microorganisms within a glacierized catchment on Svalbard, High Arctic. Polar Biology, 33: 737-745. http://dx.doi.org/10.1007/s00300-009-0751-x
Rivkina E., Laurinavichius K., McGrath J., Tiedje J., Shcherbakova V. \& Gilichinsky D., 2004 - Microbial life in permafrost. Advances in Space Research, 33: 1215-1221. http://dx.doi.org/10.1016/j.asr.2003.06.024

Roth V., 2006 - http://www.doubling-time.com/compute. php [accessed: July 28, 2014].

Rusu T., Racoviță G. \& Coman D., 1970 - Contribution à l'étude du complexe karstique de Scărişoara. Annales de Spéléologie, 25: 383-408.

Segawa T., Ushida K. , Narita H., Kanda H. \& Kohshima S., 2010 - Bacterial communities in two Antarctic ice cores analyzed by 16S rRNA gene sequencing analysis. Polar Science, 4: 215-227. http://dx.doi.org/10.1016/j.polar.2010.05.003

Şerban M., Coman D. \& Givulesco R., 1948 - Decouvertes récentes et observations sur la glacière naturelle dite Ghețarul de la Scărişoara", Bulletin de la Société des Sciences de Cluj, 10: 174-210.

Skidmore M.L., Foght J.M. \& Sharp M.J., 2000 Microbial life beneath a high arctic glacier. Applied and Environmental Microbiology, 66: 3214-3220.

http://dx.doi.org/10.1128/AEM.66.8.3214-3220.2000

Talavera G. \& Castresana J., 2007 - Improvement of phylogenies after removing divergent and ambiguously aligned blocks from protein sequence alignments. Systematic Biology, 56: 564-577.

http://dx.doi.org/10.1080/10635150701472164

Varin T., Lovejoy C., Jungblut A.D., Vincent W.F. \& Jcorbeiladin J., 2010 - Metagenomic profiling of Arctic microbial mat communities as nutrient scavenging and recycling systems. Limnology and Oceanography, 55: 1901-1911.

http://dx.doi.org/10.4319/10.2010.55.5.1901

Vesterdal L., Schmidt I.K., Callesen I., Nilsson L.O. \& Gundersen P., 2008 - Carbon and nitrogen in forest floor and mineral soil under six common European tree species. Forest Ecology and Management, 255: 35-48. http://dx.doi.org/10.1016/j.foreco.2007.08.015

Yu D. \& Margesin R., 2014 - Partial characterization of a crude cold-active lipase from Rhodococcus cercidiphylli BZ22. Folia Microbiologica, 59: 439-445. http://dx.doi.org/10.1007/s12223-014-0318-2

Zak K., Onac B.P. \& Perşoiu A., 2008 - Cryogenic carbonates in cave environments: a review. Quaternary International, 187: 84-96. http://dx.doi.org/10.1016/j.quaint.2007.02.022

Zumsteg A., Luster J., Göransson H., Smittenberg R.H., Brunner I., Bernasconi S.M., Zeyer J. \& Frey B., 2012 Bacterial, archaeal and fungal succession in the forefield of a receding glacier. Microbial Ecology, 63: 552-564. http://dx.doi.org/10.1007/s00248-011-9991-8 